Bilge, H. (2022). 2006-2019 yılları arasında kullanılan Türkçe öğretim programlarının akıcı yazma becerisi açısından karşılaştııılması. Ana Dili Eğitimi Dergisi, 10(1), 199-215.

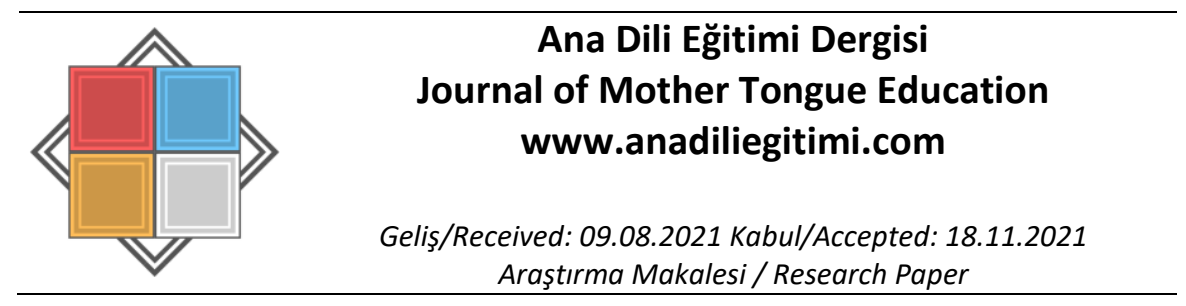

\title{
2006-2019 Yılları Arasında Kullanılan Türkçe Öğretim Programlarının Akıcı Yazma Becerisi Açısından Karşılaştırılması*
}

\author{
Huzeyfe BiLGE**
}

\begin{abstract}
Özet
Bu çalışmanın hedefi 2006, 2009, 2015 ve 2019 Türkçe öğretim programlarındaki akıcı yazmanın yerini incelemek ve karşılaştırmaktır. Nitel desende yürütülen çalışmada doküman incelemesi yapılmış ve bulgular betimleyici istatistiklerle (frekans ve yüzde) sunulmuştur. Çalışmanın bulgularında akıcı yazmanın terim olarak geçtiği hiçbir kazanıma rastlanmamıştır. Akıcı yazmanın hız boyutuyla ilgili sadece bir kazanımın olduğu; imlâ bakımından kelimelerin doğru yazılmasıyla ilgili kazanımların nispeten daha çok olduğu tespit edilmiştir. Akıcı yazmanın doğruluk boyutunda müfredatlar ve sınıf seviyeleri arasında önemli tutarsızlıkların olması da bulgular arasındadır. Genel olarak bakıldığında akıcı yazmanın son 15 yıldır göz ardı edildiği sonucuna ulaşılmıştır. Çalışmanın bulguları alan yazın ışığında tartışılmıştır.
\end{abstract}

Anahtar Kelimeler: Akıcı yazma, yazma hızı, yazma doğruluğu, Türkçe öğretim programları, yazma becerisi

\section{Comparison of Turkish Language Arts Curricula Used Between 2006-2019 in terms of Writing Fluency Skills}

\section{Abstract}

The aim of this study was to examine and compare the place of writing fluency in Turkish language arts teaching curricula used in 2006, 2009, 2015, and 2019. In this qualitative study, document analysis was carried out and the findings are presented with descriptive statistics (frequency and percentage). In the findings of the study, no learning outcomes mentioning writing fluency as a term were found. There was only one learning outcome regarding the speed dimension of writing fluency. In terms of spelling, the learning outcomes related to accurate writing of words were relatively higher. It was also found that there are significant inconsistencies between the curricula and grade levels for the accuracy dimension of writing fluency. In general, it is concluded that writing fluency has been ignored for the last 15 years. The findings of the study are discussed by considering the related scientific literature.

Keywords: Writing fluency, writing speed, writing accuracy, Turkish teaching curricula, writing skill

\section{Giriş}

Yazılı bir metnin oluşturulmasında zihinle ilgili çok karmaşık süreçler gerçekleşir. Yazmanın nasıl gerçekleştiğini açıklamaya yönelik öne sürülen biliş süreci modellerinde üretim, aktarma ve gözden geçirme süreçlerinin varlığı araştırmacılarca müşterek bir kabuldür (Alamargot ve Fayol, 2009; Beard, Myhill, Riley ve Nystrand, 2009). Bu süreçlerden herhangi birindeki aksaklık bütün süreci etkileyebilir.

\footnotetext{
* Bu çalışma 21-23 Ekim 2020 tarihinde düzenlenen "XII. Uluslararası Dünya Dili Türkçe Sempozyumu"nda "Yapılandırmacı Yaklaşıma Göre Hazırlanmış Türkçe Öğretimi Programlarında Akıcı Yazma" ismiyle sözlü bildiri olarak sunulmuştur.

** Dr. Öğr. Üyesi, Kafkas Üniversitesi, Dede Korkut Eğitim Fakültesi, Türkçe Eğitimi A.B.D., Kars, hbilge@outlook.com.tr , ORCID: orcid.org/0000-0001-7664-488X
} 
Yazma becerisinin edinimi sürecinde ilk aşamalardan birisi harflerin ve kelimelerin doğru bir şekilde kâğıda aktarılmasıdır. İlk yazma sürecinde öğrencilerin etkili bir metin oluşturabilmeleri için kelimeleri doğru yazabilmeye ek olarak dil bilgisini bilmesi, motor becerilerinin yeterince gelişmiş olması, muhteviyata yeterince hâkim olması da gerekir (Alamargot ve Fayol, 2009). Ancak pek çok çocuğun çeşitli sebeplerden dolayı yazmanın muhtelif boyutlarında zorluk çektikleri bilinmektedir (Dockrell, 2009; Kaptan, 2015; Kaynaş, 2014). Özellikle ortaokul seviyesinde olmasına rağmen yazamayan öğrencilere yönelik bulgular (Bilge, 2015) yazma becerisinde öğrencilerin ciddi sorunlar yaşadıklarını göstermektedir. Öğrencilerin yaygın olarak zorluk yaşadıkları boyutlardan birisi de akıcı yazmadır (Montgomery, 2005).

Akıcı yazmanın tanımlarında hız, doğruluk, zorlanmadan yazma, fikirler arasında tutarlılık gibi farklı unsurlar olsa da (Hudson, 2002; Lannin, 2007; Wolfe-Quintero, İnagaki ve Kim, 1998) akıcı yazmada genelde hız ve zaman bakımından ölçümlerin yapıldığı görülmektedir. Wolfe-Quintero ve diğerleri (1998, s.14) "Akıcılık kelimelerin veya yapıların ne kadar üst seviye veya doğru olduğunun ölçümü değildir bunun yerine yazarların belli bir zaman dönemi içinde yazılarına katabildikleri kelime veya yapı birimlerinin katıksız sayısıdır." diyerek akıcı yazmada kalite, doğruluk gibi farkı boyutları hızdan ayrı kabul etmiştir. Yapılan pek çok çalışmada da akıcılık ölçümü olarak hızın esas alındığı, birim başına düşen harf, kelime, yancümle, cümle gibi unsurların sayısının ölçüldüğg̈ görülmektedir (Berninger ve Fuller, 1992; Bilge, 2019; Hestad, 2014; Hudson, 2002; Lannin, 2007). Buradan yola çıkarak akııı yazmanın alan yazında genelde yazma hızı manasında kullanıldığı söylenebilir. Ancak burada kelimelerin ve harflerin doğru yazılmaksızın "katıksız hız" ölçümlerinin yapıldığı söylenemez. Bunun yerine, harflerin ve kelimelerin doğru ve hızlı yazılması gerektiği açıktır.

Bir kişinin akıcı yazabilmesi harf oluşturma, kelimeleri doğru kodlama gibi düşük seviyeli işlemlerde otomatikleşmesine bağılır (Hudson, 2002). Yazmanın mekaniklerine odaklanmak yazılacakların unutulmasına sebep olabileceği için (Christensen, 2009; Graham, Berninger, Abbott, Abbott ve Whitaker, 1997) işleyen hafızanın düşük seviyeli işlemler yerine planlama, içerik, hedef kitleye uygun yazma gibi üst seviyeli işlemlere ayrılması gerekir (Berninger, 1999). Burada işleyen hafıza hayati bir öneme sahiptir. Çünkü içerik, hedef kitleye uygunluk, dil bilgisi gibi uzun süreli hafızada yer alan bilgiler (Hayes, 2009) kısa süreli hafızaya geldiğinde unutulmadan kâğıda aktarılmalıdır. Bu bilgilerin kısa süreli hafızada korunabilmesi (Alamargot ve Fayol, 2009) için dikkatin başka yöne kaymaması gerekir. Dikkat başka yöne kaymadığında içerik uzun süreli hafızadan kesintisiz bir biçimde getirilebilir (Galbraith, 2009; Graham ve Weintraub, 1996). Dolayısıyla yazmada "asıl hedef" olarak nitelendirilebilecek boyutlardan olan hedef kitleye görelik, içerik, tutarlıık gibi daha karmaşık süreçlere erişmek için öncelikle akıcılık kazanmak gerektiği söylenebilir. Aksi takdirde öğrencilerin kelimeleri ve harfleri doğru yazmaya odaklanması ve üst seviyeli süreçlere yeterli zaman ve enerji ayıramamaları söz konusu olabilir. Bu durumda anlamadan doğru okuyan öğrencilerin aslında okumadığının kabul edilmesi gibi (Stanovich, 2009), yazımı doğru olsa da gerçek manada yazamayan öğrencilerin ortaya çıkması söz konusu olabilir.

Akıcı yazmanın ehemmiyeti sadece nitelikli yazmayla alakalı değildir. Alan yazındaki çalışmalar akıcı yazmanın okuduğunu anlama gibi diğer becerilerle ve akademik başarıyla ilişkisini ortaya koymaktadır (Ahmed, 2011; Appleton, 1992; Bilge, 2019; Couvillion, 1985). Fakat akıcı yazmanın özellikle akademik başarıyla olan ilişkisi dikkat çekicidir. Araştırmacılar ortaokul seviyesindeki müfredat gerekliliklerini karşılamak için öğrencilerin yazmalarında tutukluluk yaşamamaları gerektiğini çünkü sınav veya dikte edici yazma gibi durumlarda hızlı ve okunaklı yazmanın çok mühim bir beceri olduğunu (Barnett, Stainthorp, Henderson ve Scheib, 2006; Montgomery, 2006) söylemektedir. Akıcı yazmaakademik başarı ilişkisine Parr, Levi ve Jacka'nın (1995) üniversite öğrencileriyle yaptığı çalışma örnek olarak verilebilir (akt. Sawyer, Francis ve Knight, 1992). Bu çalışmada üniversite öğrencileri sınavlarda yazacaklarını yetiştiremediklerini ve daha fazla süre istediklerini ifade etmiştir. Sınavlarda ve hızlı not almanın gerektiği durumlarda yazma hızı önemli olduğundan (Montgomery, 2006; Sassoon, 2006) öğrenim kademelerinin her birinde, akademik başarı için akıcı ve tutukluk göstermeden yazmanın gerekli olduğu sonucuna varılabilir.

Akıcı yazma akademik başarı açısından çok mühim bir beceri olsa da öğrenciler arasında oldukça yaygın bir problem gibi görünmektedir. İngiltere'de öğrenciler arasında akıcı yazmayla ilgili 7. 
sınıf seviyesindeki öğrencilerin en az üçte birinin yazma kıstaslarını karşılayamadığı ve en az yüzde 10'unun disleksik kategoride yer alacak kadar zayıf olduğu tespit edilmiştir (Montgomery, 2005). Ingiltere'de yapılan başka çalışmalarda da öğrencilerin akıcı yazamamalarıyla ilgili çeşitli sorunlar tartışıımaktadır ve araştırmacılar öğrencilere akıcı yazmanın öğretilmesi gerektiğini ifade etmektedir (Montgomery, 2006; Sassoon, 2005). Ülkemizde ise üniversiteye kadar (Çamurcu, 2011) çeşitli seviyelerde yazmayla ilgili sorunların varlığı bilinmektedir. Araştırmacılara göre yaşanan yazma zorluklarının muhtemel sebeplerinden birisi yazmayla ilgili müfredat veya sınıf içi uygulamalardır (Englert vd. 1988'den aktaran; Berninger ve Fuller, 1992). Bu nedenle İngiltere'de ve Amerika'da öğrencilerin akıcı yazabilmelerini sağlamak için müfredatlarda çeşitli vurgular yapıldığı ve akıcı yazmanın önemine değinildiği görülmektedir.

Akıcı yazmayla ilgili İngiltere'de 1989 yılında yürürlüğe konan Yazma ve Sunum Üzerine Millî Program'da (The National Curriculum (1989) on Handwriting and Presentation'dan aktaran; Montgomery, 2006) çeşitli hedeflerin olması dikkat çekicidir. Bu müfredatta Aşama 2'de ve 3'te öğrencilerin hızlı, akıcı ve okunaklı yazabilmelerine yönelik hedefler bulunmaktadır. Hatta İngiltere'de yazma hızıyla ilgili dakika başına birim hedefleri bulunmaktadır (Montgomery, 2005). Amerikan Ulusal Yazma Komisyonu (National Comission on Writing, 2003) yazmanın genelde ihmal edilen bir beceri olduğunu ve akıcı yazmanın eğitimin en temel ögelerinden biri olduğunu ifade etmektedir. Bu görüş, yazma hızının eğitimde önemli olduğunu düşünen araştırmacılarca (Montgomery, 2006; Sassoon, 2006; Ziviani ve Elkins, 1984) desteklenmektedir. Ayrıca Amerika'da öğrencilerin akıcı yazmalarııın 1984'ten beri itibaren takip edildiği bilinmektedir (Ballator vd., 1999). İngiltere ve Amerika'da ulusal seviyede akıcı yazmaya ciddi bir önemin verildiği görülse de ülkemizde akıcı yazmanın gereken öneme sahip olmadığı söylenebilir. Akıcı yazma üzerine yapılan tezlerdeki sayının oldukça kısıtlı olması (YÖKTEZ, 2020) bu konunun göz ardı edildiğinin göstergelerinden biridir.

Yazmada akıcılık (hız) Türkiye'de de kimi araştırmacılarca önemli bir beceri olarak ele alınmaktadır. Akyol (2015) özellikle birinci sınıflardaki öğrencilerin yazma hızlarının geliştirilmesi gerektiğini, bunun yazma becerisi eğitimindeki iki önemli unsurdan bir olduğu söylemektedir. Akıcı yazmaya okullarda mutlaka yer verilmesi gerektiği alan yazında sıkça ifade edilmektedir (Barnett vd., 2006; Sassoon, 2006). Hatta Ziviani ve Elkins (1984) hızlı yazabilmenin temel bir eğitim becerisi olduğunu ifade etmektedir. Ancak mevcut Türkçe öğretimi müfredatında (MEB, 2019) yazmada okunaklııı̆ın hedeflendiği ifade edilirken akıcı yazmayla ilgili bir açıklama tespit edilememiştir. Dolayısıyla ilk okuma yazmada, yazma becerisinde hedeflenen iki beceriden (Akyol, 2015) sadece birisine yer verilmiştir. Hâlbuki özellikle ortaokulun son kademelerindeki yazma becerisi kazanımlarına (MEB, 2019) ulaşmak için öncelikle akıcı yazma becerisinin kazanılması gerekmektedir.

Yukarıdaki açıklamalardan yola çıkarak, bu çalışmada 2006, 2009, 2015 ve 2019 Türkçe öğretim müfredatlarında akıcı yazma becerisinin yerinin incelenmesi hedeflenmiştir. Böylece akıcı yazmayla ilgili son on beş yılda ne kadar kazanıma yer verildiği, müfredatlar arasında bir tutarlılık olup olmadığı tespit edilebilecektir. Araştırmada aşağıdaki soruların cevapları aranmıştır:

1. 1-2006, 2009, 2015 ve 2019 müfredatlarında yazma becerisinde kazanımların kaç tanesi akıcı yazma becerisiyle (ve alt boyutlar olan hız ve doğrulukla) ilgili veya ilgisizdir?

2. 2-2006, 2009, 2015 ve 2019 müfredatlarında yazma becerisinde akıcı yazmayla (ve alt boyutlar olan hız ve doğrulukla) ilgili kazanımların sayılarının sınıf seviyelerine göre dağııımları nasıldır?

3. 3-2006, 2009, 2015 ve 2019 müfredatlarında yazma becerisinde akıc yazma becerisiyle (ve alt boyutlar olan hız ve doğrulukla) ilgili kazanımların sınıf seviyelerine göre toplam yazma becerisi kazanımına oranları nedir?

4. 4- Akıcı yazmada hız ve doğrulukla ilgili kazanımların müfredatlar arasındaki dağılımı nasıldır? 


\section{Araştırmanın Modeli}

\section{Yöntem}

Bu çalışmada 2006, 2009, 2015 ve 2019 yıllarında yürürlüğe konmuş olan Türkçe öğretimi müfredatlarında akıcı yazmanın yeri incelenmiştir. Nitel desende yürütülen araştırmanın veri toplama yöntemi doküman incelemesidir. Doküman incelemesi tek başına kullanılabildiği gibi diğer nitel yöntemlere ek olarak da kullanılabilen ve çok çeşitli belgeleri (fotoğraf, kitap vb.) incelemeye yarayan yöntemdir (Yıldırım ve Şimşek, 2004). Bu çalışmada dokümanlar var oldukları şekliyle incelendiği için doküman incelemesi yöntemi tercih edilmiştir.

\section{Veri Kaynağı}

Bu araştırmada veri kaynağı olarak Millî Eğitim Bakanlığınca yayımlanmış müfredatlar kullanılmıştır. Bu kapsamda dört Türkçe öğretimi müfredatı araştırmanın temel veri kaynağını oluşturmaktadır (MEB, 2006, 2009; 2015, 2019). 2017 ve 2018 müfredatları 2019 müfredatıyla neredeyse aynı olduğu için kapsam dışı bırakılmıştır.

Kazanımların akıcı yazmayla alakalı olup olmadıklarını değerlendirmek için "Akıcı Yazmayla İlgili Kazanımları Tespit Etme Formu" oluşturulmuştur. Bu formda her müfredattaki yazma kazanımları listelenmiştir. Her kazanımı değerlendirmek için "Alakasız" ve "Alakalı" sütunları açılmıştır. "Alakalı" sütunun altına "Hız" ve "Doğruluk" olmak üzere ikişer sütun daha açılmıştır. Formun doldurulmasında bir kazanım birden fazla boyutla ilgili olarak değerlendirilebilmiştir. Formun değerlendirme yapılmış hâli ile ilgili örnek Şekil 1'de gösterilmiştir.

\section{6-8 Türkçe Öğretimi Programı}

\begin{tabular}{|c|c|c|c|}
\hline \multirow[b]{2}{*}{ Yazım Kurallarını Uygulama } & \multirow[t]{2}{*}{ Alakasız } & \multicolumn{2}{|r|}{ Alakalı } \\
\hline & & Hiz & Doğru Yazma \\
\hline Kâğıt ve sayfa düzenine dikkat eder. & $\mathrm{X}$ & & \\
\hline $\begin{array}{l}\text { Düzgün, okunaklı ve ișlek "bitișik eğik yazı"yla yazar. } \\
\text { (Bu maddenin programdaki açıklamasına bakılmalıdır) }\end{array}$ & & $\mathrm{X}$ & $\mathrm{X}$ \\
\hline Elektronik ortamdaki yazıșmalarda biçim ile ilgili kurallara uyar. & $\mathrm{X}$ & & \\
\hline Standart Türkçe ile yazar. & & & $\mathrm{X}$ \\
\hline Türkçenin kurallarına uygun cümleler kurar. & $\mathrm{X}$ & & \\
\hline $\begin{array}{l}\text { Yabancı dillerden alınmış, dilimize henüz yerleşmemiş kelimelerin } \\
\text { yerine Türkçelerini kullanır. }\end{array}$ & $\mathrm{X}$ & & \\
\hline
\end{tabular}

Şekil 1. Değerlendirme Yapılmış Örnek Formdan Bir Görüntü

\section{Verilerin Analizi}

Doküman incelemesinin yapıldığı bu araştırmada verilerin analiz edilmesi için betimsel analiz kullanılmıştır. Betimsel analiz nitel araştırma türlerinde kullanılabilen ve önceden karar verilmiş sınıflara göre değerlendirme yapılan, okuyuculara betimleyici verileri sunmanın hedeflendiği analiz türüdür (Yıldırım ve Şimşek, 2004).

Verilerin analizine geçilmeden evvel akıcı yazmayla ilgili literatürdeki tanımlar gözden geçirilmiştir. Pek çok farklı tanım ve ölçüm olduğu için Türkiye'de uygulanan çalışmalardan Bilge'nin (2019) araştırmasındaki akıcı yazma ölçümleri esas alınmıştır. Buna göre akıcı yazmada hız ve kelimelerin sadece imla olarak doğru yazılmasına yönelik kazanımların olup olmadığı incelenmiştir. Anlatım bozuklukları "doğruluk" boyutunda değerlendirilmemiştir.

Formlar doldurulurken bir kazanımın birden fazla akıcı yazma boyutunda işaretlenmesi de zaman zaman tercih edilmiştir. Mesela 2006 (MEB) müfredatındaki "Düzgün, okunaklı ve işlek 'bitişik eğik yazı'yla yazar." kazanımı hem hız hem de doğruluk boyutunda kabul edilmiştir. Birden fazla boyutta işaretlenen kazanımlar tablolardaki "Toplam" sütununda "*" işareti ile belirtilmiştir.

Elde edilen verilerle akıcı yazmayla alakalı olan veya olmayan kazanımların toplam sayıları ve yüzdeleri hesaplanmıştır. Analizler frekans ve yüzde olarak sunulmuştur. Verilerin anlaşıımasında kolaylık olması açısından 2009 ve 2006 müfredatı birlikte ele alınmıştır. 
2006-2019 Yılları Arasında Yürürlüğe Konmuş Türkçe Öğretim Programlarının Akıcı Yazma Becerisi Bakımından Karşılaştırılması

\section{Geçerlik ve Güvenirlik}

Nitel çalışmalardaki geçerlilik ve güvenilirlik konuları nicel çalışmalardakinden farklıdır. Araştırmacıların nitel çalışmalardaki geçerlilik ve güvenilirlik konularıyla ilgili görüşleri birbirinden farklılaşmaktadır (Miles, Huberman ve Saldana, 2014; Patton, 2002; Silverman, 2018). Bu araştırmada üçgenleme tekniğine başvurulmuştur. Bu teknikte tutarlılığı artırmak ve tarafsızlığı azaltmak için birden fazla değerlendirici birbirinden bağımsız bir şekilde değerlendirme yapmaktadır (Patton, 2002).

Araştırmada incelenen dört müfredattaki bütün yazma kazanımları araştırmacı tarafından formda işaretlenmiştir. Ardından aynı form Türkçe eğitimi alanında doktora yapmış bir akademisyen tarafından da doldurulmuştur. Sonra iki değerlendirici bir araya gelerek görüş ayrılığı yaşanan kazanımları değerlendirerek kimilerinde ortak görüşe varmış kimilerinde görüş ayrılı̆̆ına devam etmiştir. Ayrılığa düşülen kazanımlarla ilgili yapılan görüşmede müfredatlar açılarak açıklamalara bakılmış ve kararlar buna göre verilmiştir. Herhangi bir müfredatta kazanımla ilgili bir açıklama yoksa önceki müfredatlardaki benzer kazanımlara yönelik açıklamalar esas alınmıştır.

Değerlendiricilerin birinci ve ikinci değerlendirmelerinin ardından elde edilen uyumlar Miles ve Huberman'ın (1994'ten aktaran; Eldeleklioğlu Onuk ve Avcı, 2021) formülüyle değerlendirilmiştir. Değerlendiriciler arası uyumla ilgili veriler Şekil 2'de gösterilmiştir.

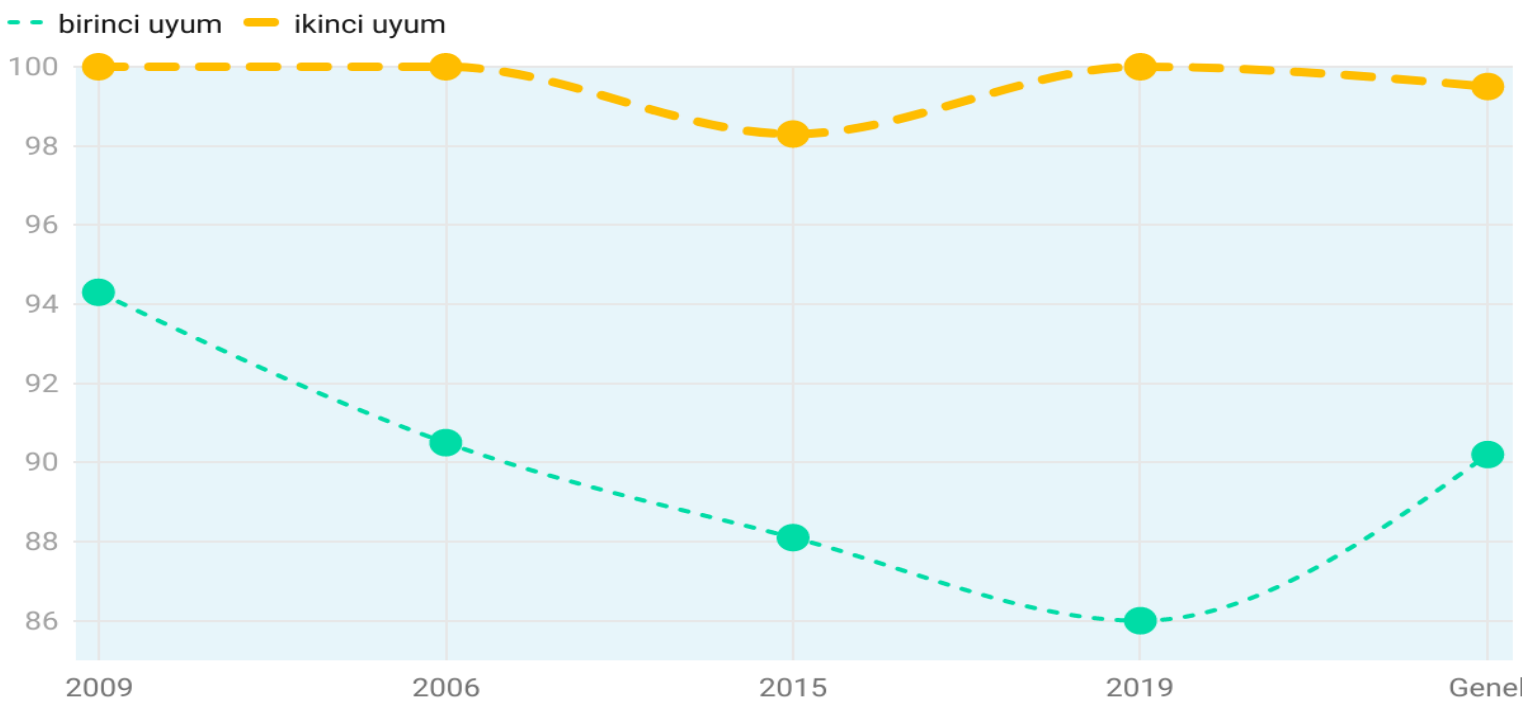

Şekil 2. Değerlendiriciler Arası Uyum Yüzdeleri

Şekil 2'deki verilerden de görüleceği üzere değerlendiriciler arası uyum 2009 müfredatında \%94'ten biraz yüksekken ikinci değerlendirmede \%100'e çıkmıştır. En düşük uyum 2019 müfredatındaki birinci değerlendirmede ortaya çıkmıştır (\%86). Ancak ikinci değerlendirmede görüş ayrılıkları giderilerek uyum \%100'e ulaşmıştır. Toplam uyum ilk değerlendirmede $\% 90$ civarındayken ikinci değerlendirmede neredeyse mükemmel bir değere ulaşmıştır. Bu değerler Miles ve Huberman'ın (2014) kıstaslarına göre çok yüksek değerlerdir.

\section{Araştırma ve Yayın Etiği}

Bu çalışmada "Yükseköğretim Kurumları Bilimsel Araştırma ve Yayın Etiği Yönergesi" kapsamında uyulması belirtilen tüm kurallara uyulmuştur. Yönergenin ikinci bölümü olan "Bilimsel Araştırma ve Yayın Etiğine Aykırı Eylemler" başlığı altında belirtilen eylemlerden hiçbiri gerçekleştirilmemiştir.

\section{Etik Kurul izni}

Bu çalışma doküman incelemesi olduğu için etik kurul izni gerektirmemektedir. 


\section{Bulgular}

Bu bölümde araştırmanın bulgularına yer verilmiştir. Öncelikle dört müfredattaki yazma becerisindeki toplam kazanım sayıları sınıflara göre karşılaştırılmıştır.

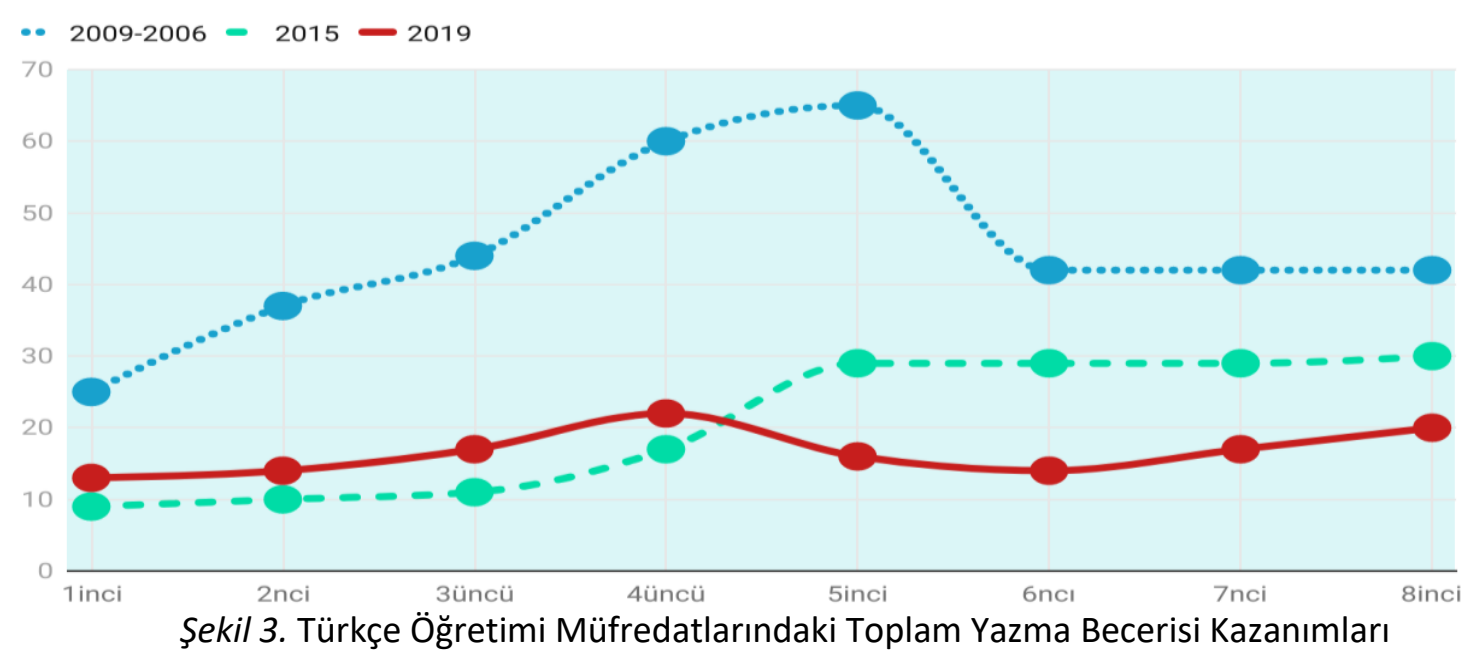

Şekil 3'te 2009-2006, 2015 ve 2019 müfredatlarında toplam yazma kazanımları verilmiştir. Buna göre 2009-2006 müfredatları toplam yazma bütün sınıf seviyelerinde diğer müfredatlardan daha fazla kazanıma sahiptir.

Birinci araştırma problemi olan "2006, 2009, 2015 ve 2019 müfredatlarında yazma becerisinde kazanımların kaç tanesi akıcı yazmayla (ve alt boyutlar olan hız ve doğrulukla) ilgili veya ilgisizdir?" sorusunun cevabına ilişkin bulgular aşağıda sunulmuştur. Tablo 1'de 2006 ve 2009 müfredatında yer alan okuma becerisi kazanımlarının akıcı yazma becerisiyle ilgilerine göre dağılımı (sayıları) verilmiştir.

Tablo 1.

2009-2006 Müfredatlarında Yazma Becerisi Kazanımlarının Akıcı Yazmayla Alakaları Bakımından Dağılımları

\begin{tabular}{|c|c|c|c|c|c|}
\hline \multirow[t]{2}{*}{ Sinıf } & \multirow[t]{2}{*}{ Alt Başlık } & \multirow[t]{2}{*}{ Alakasız } & \multicolumn{2}{|c|}{ Alakalı } & \multirow[b]{2}{*}{ Toplam } \\
\hline & & & $\mathrm{HIz}$ & Doğruluk & \\
\hline 1 & \multirow[t]{6}{*}{ Yazma Kurallarını Uygulama } & 8 & 0 & 2 & 10 \\
\hline 2 & & 8 & 0 & 3 & 11 \\
\hline 3 & & 9 & 0 & 3 & 12 \\
\hline 4 & & 12 & 0 & 2 & 14 \\
\hline 5 & & 12 & 0 & 2 & 14 \\
\hline $6-8$ & & 9 & 1 & 2 & $11^{*}$ \\
\hline 1 & \multirow[t]{5}{*}{ Kendini Yazılı Olarak Ifade Etme } & 7 & 0 & 0 & 7 \\
\hline 2 & & 16 & 0 & 0 & 16 \\
\hline 3 & & 19 & 0 & 0 & 19 \\
\hline 4 & & 32 & 0 & 0 & 32 \\
\hline 5 & & 35 & 0 & 0 & 35 \\
\hline $6-8$ & Planlı Yazma & 12 & 0 & 0 & 12 \\
\hline 1 & \multirow{5}{*}{$\begin{array}{l}\text { Tür, Yöntem ve Tekniklere Uygun } \\
\text { Yazma }\end{array}$} & 5 & 0 & 3 & 8 \\
\hline 2 & & 8 & 0 & 2 & 10 \\
\hline 3 & & 13 & 0 & 0 & 13 \\
\hline 4 & & 14 & 0 & 0 & 14 \\
\hline 5 & & 16 & 0 & 0 & 16 \\
\hline \multirow{2}{*}{$6-8$} & Farklı Türlerde Metinler Yazma & 4 & 0 & 0 & 4 \\
\hline & Kendi Yazdıklarını Değerlendirme & 2 & 0 & 1 & 3 \\
\hline
\end{tabular}


2006-2019 Yılları Arasında Yürürlüğe Konmuş Türkçe Öğretim Programlarının Akıcı Yazma Becerisi Bakımından Karşılaştırılması

Kendini Yazılı Olarak ifade Etme

Alışkanlığı Kazanma

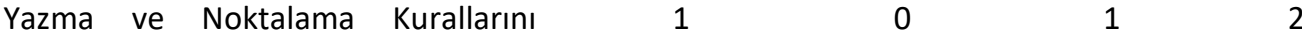

Uygulama

\begin{tabular}{lcccc}
\hline Toplam & $252(\% 92,3)$ & $1(\% 0,36)$ & $21(\% 7,69)$ & 273 \\
\hline *Bazı kazanımlardan birden fazla akıcılık boyutu yer almaktadır. Bu nedenle birden fazla boyutta işaretleme \\
yapılmıştır.
\end{tabular}

Tablo 1'de gösterildiği üzere akıcı yazmada hızla ilgili sadece 2006 müfredatında 6-8. sınıflardaki bir kazanımda bir ifade geçmektedir. Bunun dışında hiçbir yerde yazma hızıyla ilgili bir ifade yoktur. Doğrulukla ilgiliyse pek çok farklı yazma alt başığında kazanımlar bulunmaktadır. Her iki müfredatta doğrulukla ilgili toplamda 21 kazanımda ifade geçmektedir. Dolayısıyla 1-8. sınıflarda doğrulukla ilgili boyuta daha fazla ehemmiyet verildiği görülmektedir.

Yazma hızıyla ilgili kazanımların bu iki müfredattaki toplam yazma kazanımına oranı \%0,36'dır. Bu oran doğrulukta \%7,69'a çıkmaktadır. Bütün yazma kazanımlarında akıcı yazmayla ilgili olanların oranı \%7,7'dir. Bu kazanımlar akıc yazmayla dolaylı olarak alakalı kazanımlardır.

2009 müfredatında akıcı yazmayla ilgili kazanımlara örnek olarak "Dikte etme çalışmalarına katılır." ve "Verilen cümle ya da metne bakarak yazar." kazanımları örnek gösterilebilir. 2006'da "Düzgün, okunaklı ve işlek "bitişik eğik yazı"yla yazar" ve "Standart Türkçe ile yazar." kazanımları misal verilebilir. Bu kazanımlarla aslında akıcı yazmanın hedeflenmediği ancak kazanımların akıcı yazmayla dolaylı olarak ilgili oldukları görülmektedir.

Tablo 2'de 2015 müfredatındaki yazma kazanımlarında akıcı yazmayla ilgili olanların sayıları ve oranları gösterilmiştir.

Tablo 2.

2015 Müfredatında Yazma Becerisi Kazanımlarının Akıcı Yazmayla Alakaları Bakımından Dağılımları

\begin{tabular}{lllll}
\hline Sınıf & Alakasız & Hız & Doğruluk & Toplam \\
\hline 1 & 7 & 0 & 2 & 9 \\
2 & 8 & 0 & 2 & 10 \\
3 & 9 & 0 & 2 & 11 \\
4 & 14 & 0 & 3 & 17 \\
5 & 25 & 0 & 4 & 29 \\
6 & 26 & 0 & 3 & 29 \\
7 & 28 & 0 & 1 & 29 \\
8 & 29 & 0 & 1 & 30 \\
\hline Toplam & $146(\% 89,02)$ & $0(\% 0)$ & $18(\% 10,98)$ & 164 \\
\hline
\end{tabular}

Tablo 2'de görüleceği üzere 2015 müfredatında yazma hızıyla ilgili hiçbir kazanımda bir ifade bulunmamıştır. Doğrulukla ilgiliyse her sınıf seviyesinde en az bir kazanım vardır. 1-8. sınıflardaki yazma kazanımlarının 18'i doğrulukla ilgilidir. Bu kazanımların toplam yazma kazanımına oranı \%10,98'dir.

2015 müfredatında akıcı yazmada doğrulukla ilgili kazanımlara örnek olarak "Yazdıklarını kontrol ederek ifade, harf, noktalama gibi yanlışları varsa bunları belirler ve düzeltir." ve "Dikte yoluyla, bakarak ve serbest yazma çalışmaları yapar." maddeleri verilebilir.

Tablo 3'te 2019 müfredatındaki yazma kazanımlarında akıcı yazmayla ilgili kazanımların sayıları ve oranları verilmiştir.

Tablo 3.

2019 Müfredatında Yazma Becerisi Kazanımlarının Akıcı Yazmayla Alakaları Bakımından Dağılımları

\begin{tabular}{lllll}
\hline Sınıf & Alakasız & Hiz & Doğruluk & Toplam \\
\hline 1 & 10 & 0 & 3 & 13 \\
\hline
\end{tabular}




\begin{tabular}{lllll}
2 & 12 & 0 & 2 & 14 \\
3 & 13 & 0 & 4 & 17 \\
4 & 16 & 0 & 6 & 22 \\
5 & 13 & 0 & 3 & 16 \\
6 & 13 & 0 & 1 & 14 \\
7 & 15 & 0 & 2 & 17 \\
8 & 19 & 0 & 1 & 20 \\
\hline Toplam & $111(\% 83,5)$ & $0(\% 0)$ & $22(\% 16,5)$ & 133 \\
\hline
\end{tabular}

Tablo 3'e bakıldığında 2019 müfredatında yazma hızıyla ilgili hiçbir kazanımın olmadığı görülmektedir. Doğrulukla ilgili toplam 22 kazanım vardır. Bu kazanımların toplam yazma kazanımına oranı \%16,5'tir.

2019 müfredatında akıcı yazmayla ilgili kazanımlara örnek olarak "Yazdıklarını gözden geçirir." ve "Yazdıklarını düzenler." maddeleri misal gösterilebilir.

Araştırmanın "2006, 2009, 2015 ve 2019 müfredatlarında yazma becerisinde akıcı yazmayla (ve alt boyutlar olan hız ve doğrulukla) ilgili kazanımların sayılarının sınıf seviyelerine göre dağılımları nasıldır?" sorusuna yönelik bulgulara aşağıda verilmiştir.

Şekil 4'te 2009 ve 2006 müfredatlarında akıcı yazmayla ilgili kazanımların sayıları boyutlara ve sınıflara göre verilmiştir.

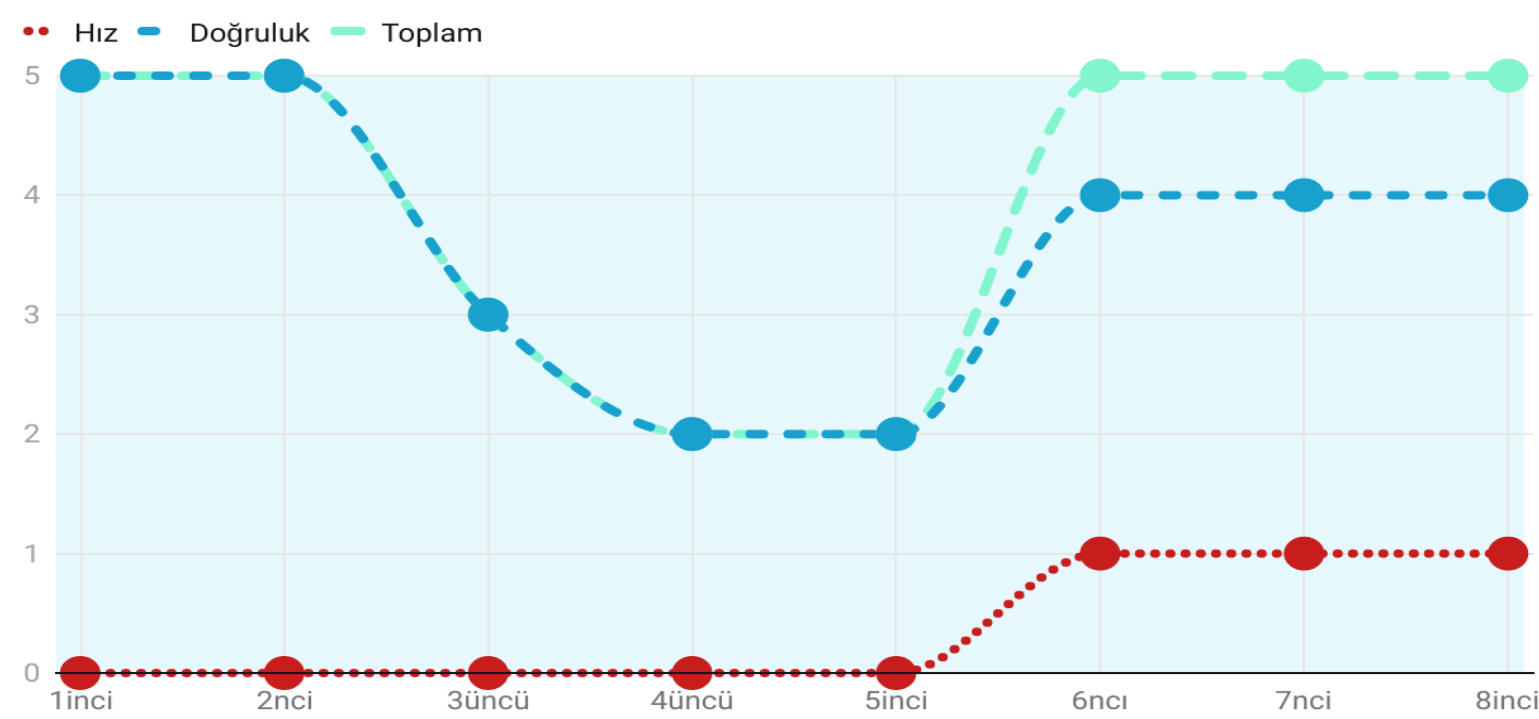

Şekil 4. 2009-2006 Türkçe Öğretimi Müfredatlarında Akıcı Yazmayla ilgili Kazanımların Hız, Doğruluk ve Toplam Bakımından Sayıları

Şekil 4'te görüleceği üzere akıcı yazmanın hız boyutuyla ilgili 1-5. sınıflarda hiçbir kazanım yoktur. 6-8. sınıflardaysa birer kazanım vardır. Doğruluk boyutunda birinci ve ikinci sınıflarda beşer kazanım varken beşinci sınıfa kadar bu sayı giderek azalmıştır. Ardından 6-8. sınıflarda tekrar artış gerçekleşerek dörder kazanıma çıkmıştır.

Şekil 52015 müfredatında akııı yazmayla ilgili kazanımların sayılarını sınıflara göre göstermektedir. 


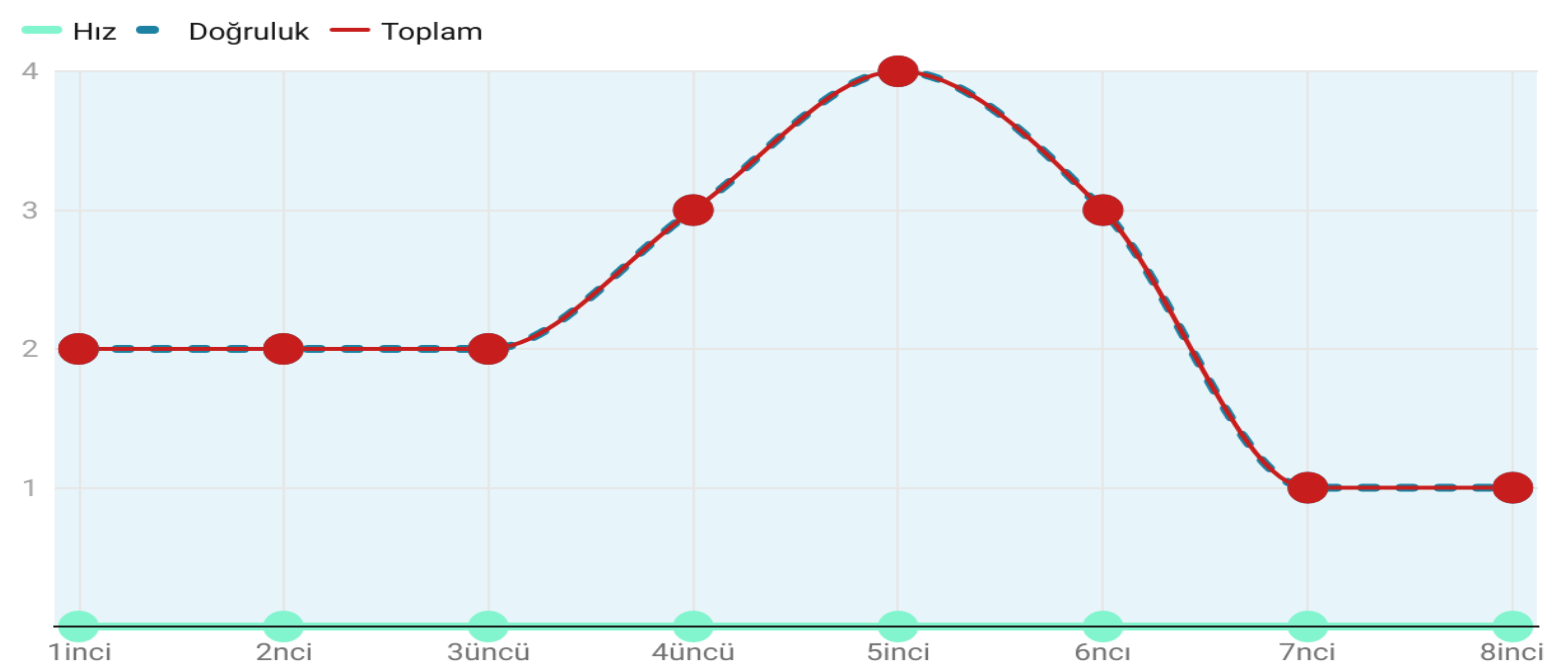

Şekil 5. 2015 Türkçe Öğretimi Müfredatında Akıcı Yazmayla ilggili Kazanımların Hız, Doğruluk Ve Toplam Bakımından Sayıları

Şekil 5'te görüleceği üzere 2015 müfredatında akıcı yazmayla ilgili kazanımların hepsini doğruluk boyutu oluşturmaktadır. Doğruluk boyutundaki kazanımların en çok beşinci sınıflarda, en az yedi ve sekizinci sınıflarda olduğu tespit edilmiştir.

Şekil 6'da 2019 müfredatında akıc yazmayla ilgili kazanımların sayıları sınıflara göre verilmiştir.

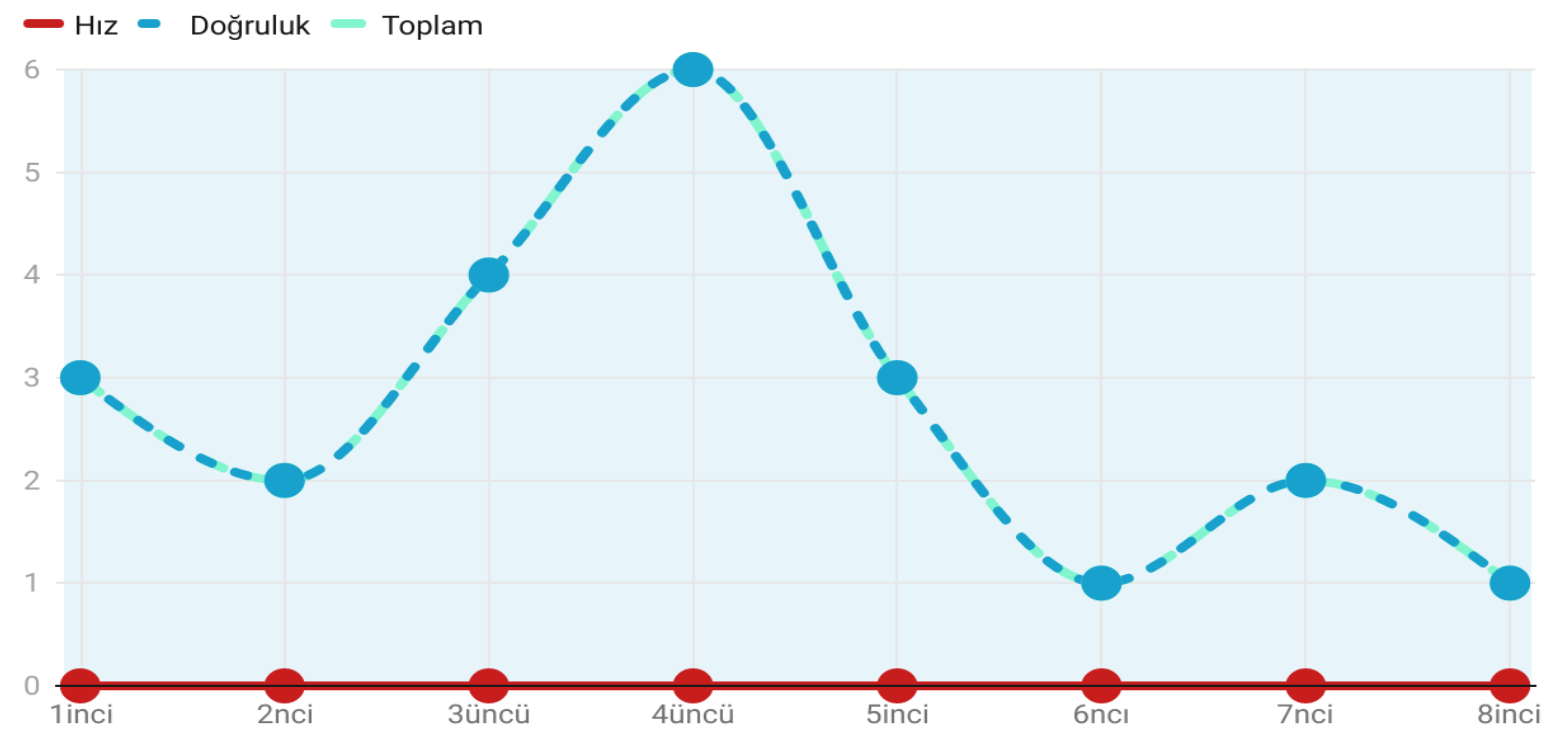

Şekil 6. 2019 Türkçe Öğretimi Müfredatında Akıcı Yazmayla İlgili Kazanımların Hız, Doğruluk Ve Toplam Bakımından Sayıları

Şekil 6'da görüleceği üzere 2019 müfredatındaki yazma kazanımlarında sadece doğruluk boyutuna yer verilmiştir. Altıncı ve sekizinci sınıflarda birer kazanımla en az yer verilen doğruluk dördüncü sınıflarda altı kazanımla zirveye ulaşmıştır.

Araştırmanın "2006, 2009, 2015 ve 2019 müfredatlarında yazma becerisinde akıcı yazma becerisiyle (ve alt boyutlar olan hız ve doğrulukla) ilgili kazanımların sınıf seviyelerine göre toplam yazma becerisi kazanımına oranları nedir?" sorusuna yönelik bulguları aşağıda verilmiştir.

Şekil 7'de 2009-2006 müfredatlarında akıcı yazmayla ilgili boyutların toplam yazma kazanımlarına oranları verilmiştir. 


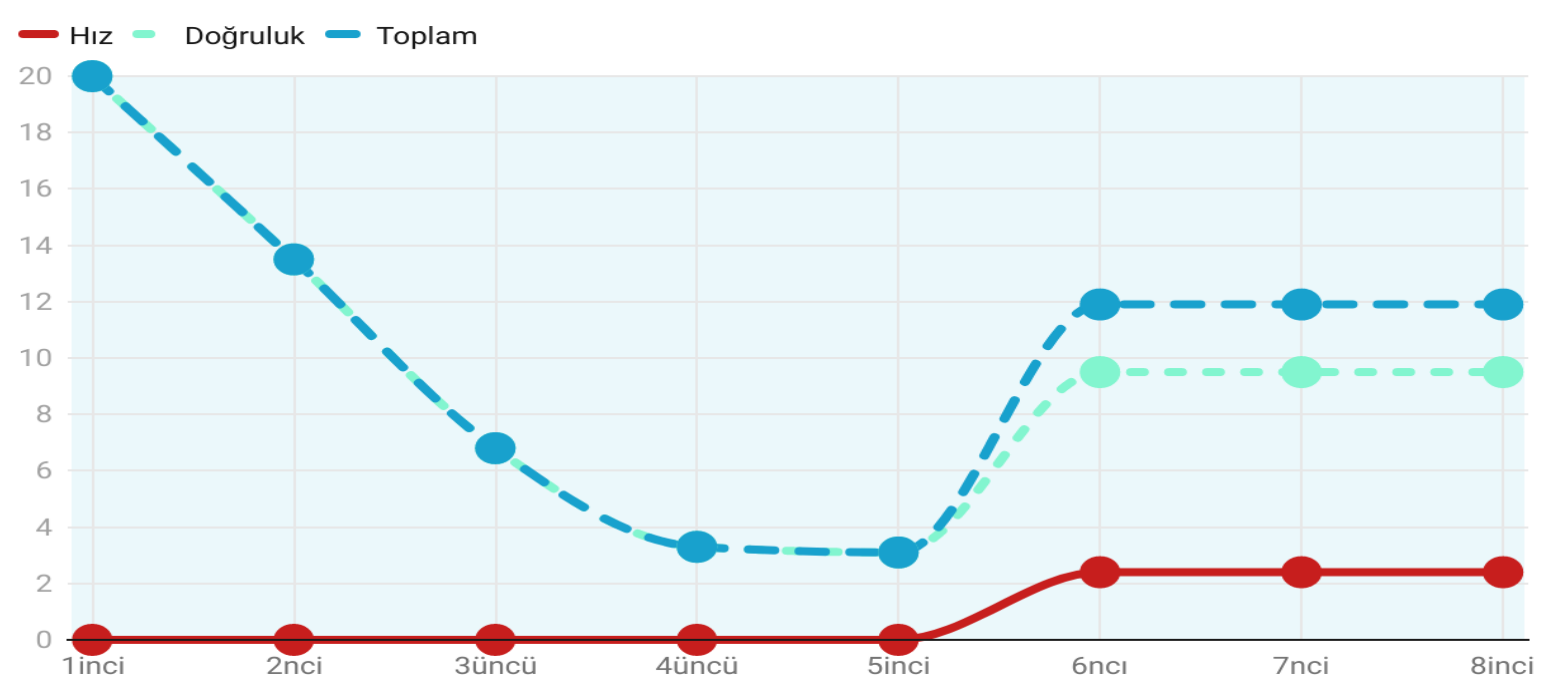

Şekil 7. 2009-2006 Müfredatlarında Akıcı Yazmayla İlgili Boyutların Toplam Yazma Kazanımlarına Oranları

Şekil 7'de görüleceği üzere 2009-2006 müfredatlarında yazmayla ilgili kazanımlarda hız boyutunun oranı 1-5. sınıflarda \%0'ken 6-8. sınıflarda \%2'nin üzerine çıkmıştır. Doğruluk boyutunda ise daha değişken bir durum görülmektedir. Birinci sınıflardaki toplam yazma kazanımında doğrulukla ilgili kazanımların oranı \%20 civarındayken bu oran 5. sınıflara doğru gittikçe düşerek \%4'ün altına inmiştir. 6-8. sınıflarda ise \%10'a yaklaşmıştır. Genel olarak bakıldığında, akıcı yazmayla ilgili kazanımların oldukça dalgalı bir orana sahip olduğu, oranların \%20-\%3 arasında değiştiği söylenebilir.

Şekil 8'de 2015'teki yazma kazanımlarında akıcı yazmanın oranı sınıf bazında verilmiştir.

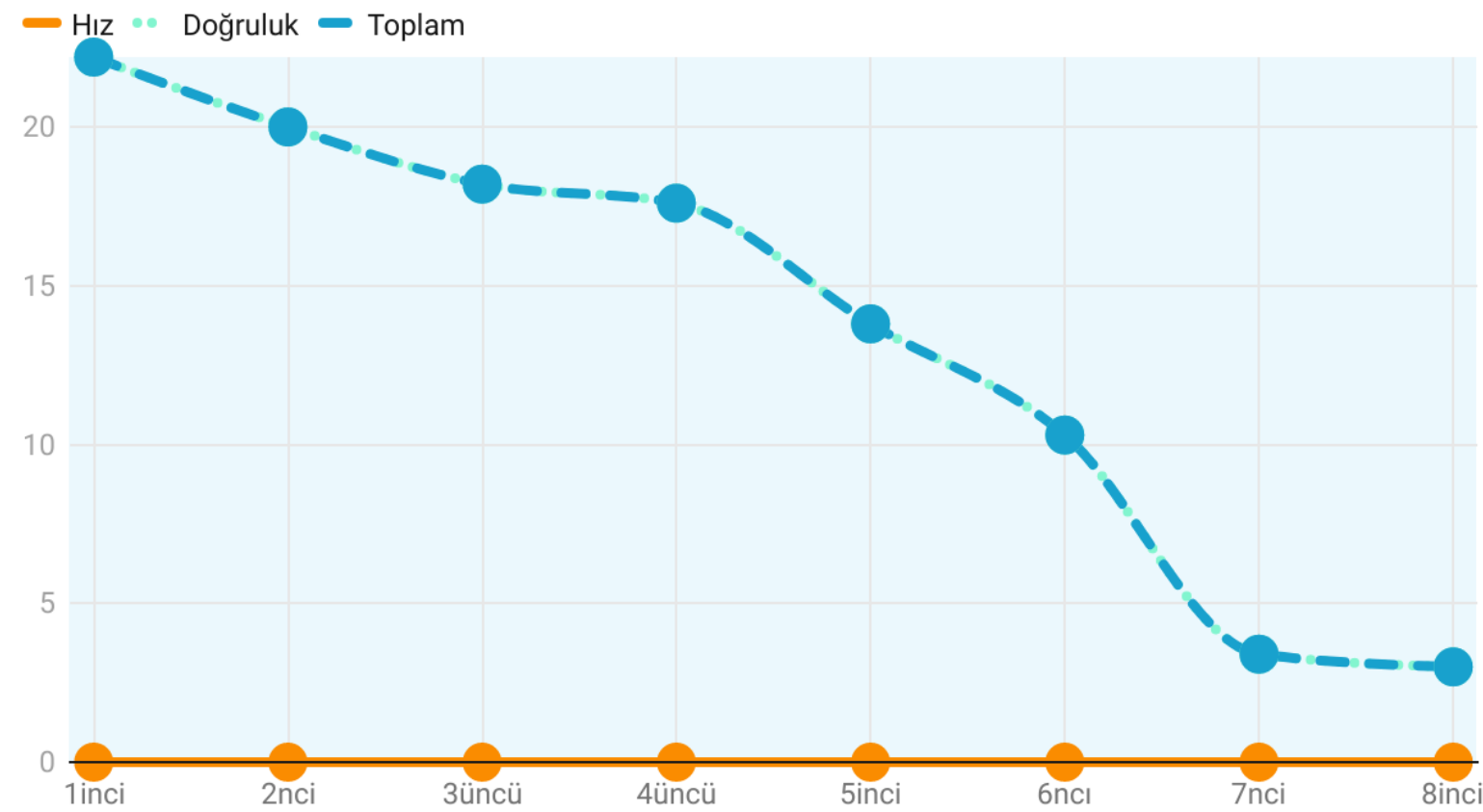

Şekil 8. 2015 Müfredatında Akıcı Yazmayla Illgili Boyutların Toplam Yazma Kazanımlarına Oranları

Şekil 8'e bakıldığında akıcı yazmayla ilgili oranların sınıf seviyesi arttıkça düzenli olarak azaldığı görülmektedir. Hızın oranı bütün sınıf seviyelerinde $\% 0$ iken doğruluğun ve toplam akıcı yazma oranının \%20'nin üzerinden \%4'ün altına doğru gerilediği anlaşılmaktadır.

Şekil 9'da 2019 müfredatındaki yazma kazanımlarında akıcı yazmanın oranının sınıf seviyelerine göre dağııımı verilmiştir. 


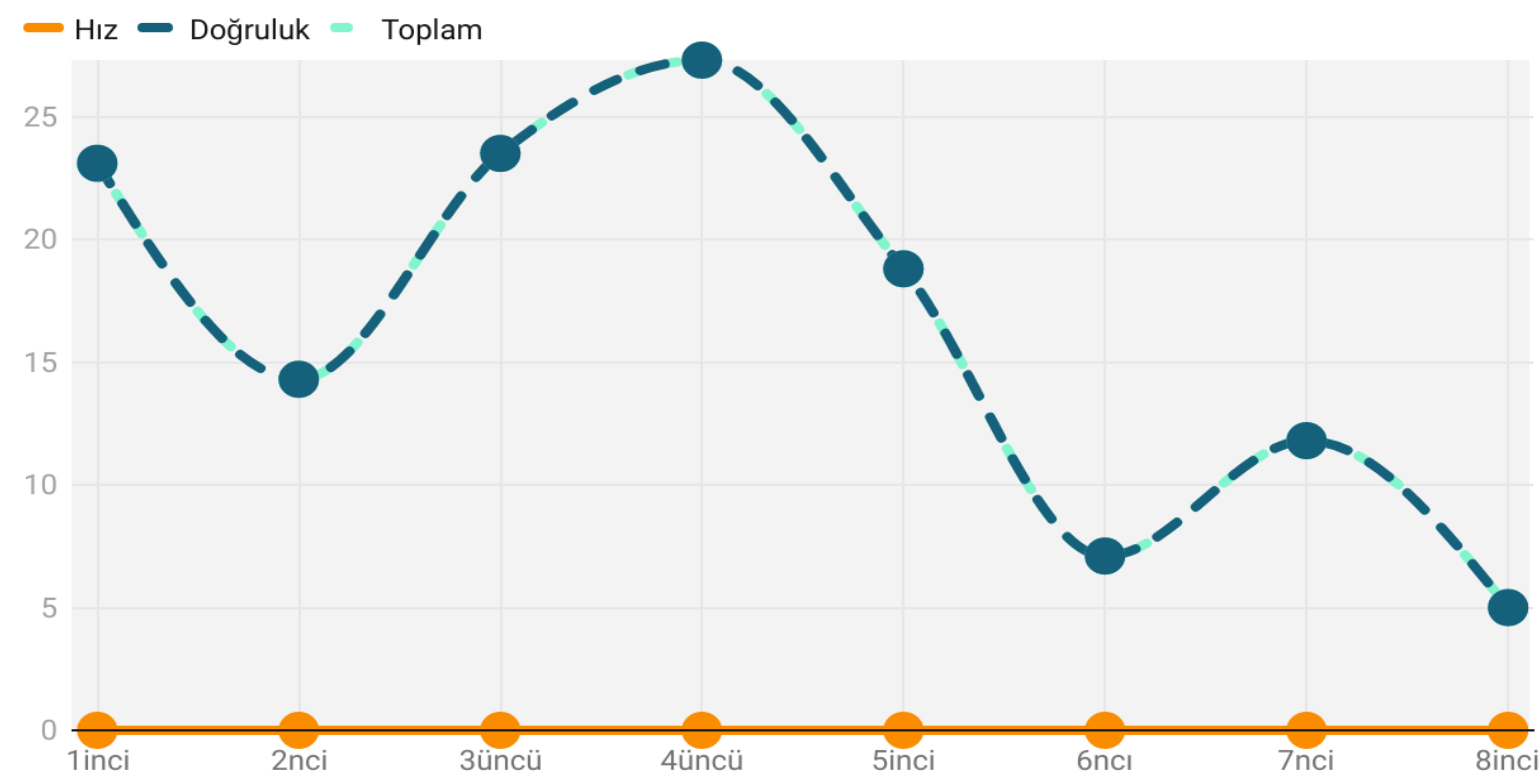

Şekil 9. 2019 Müfredatında Akıcı Yazmayla Illgili Boyutların Toplam Yazma Kazanımlarına Oranları

Şekil 9'da görüleceği üzere akıcı yazmanın hız boyutuyla ilgili 2019 müfredatında hiç kazanım bulunmamaktadır. Doğruluk boyutunda ise değişkenlik söz konusudur. Dördüncü sınıflarda \%25'i geçen oran sekizinci sınıflarda \%5'e kadar gerilemiştir.

Araştırmanın "Akıcı yazmada hız ve doğrulukla ilgili kazanımların müfredatlar arasındaki dağılımı nasıldır?" sorusuna yönelik bulgulara aşağıda yer verilmiştir.

Şekil 10'da 2009-2006, 2015 ve 2019 müfredatlarında yazma hızıyla ilgili kazanımların ilgili sınıftaki toplam yazma kazanımına oranı verilmiştir.

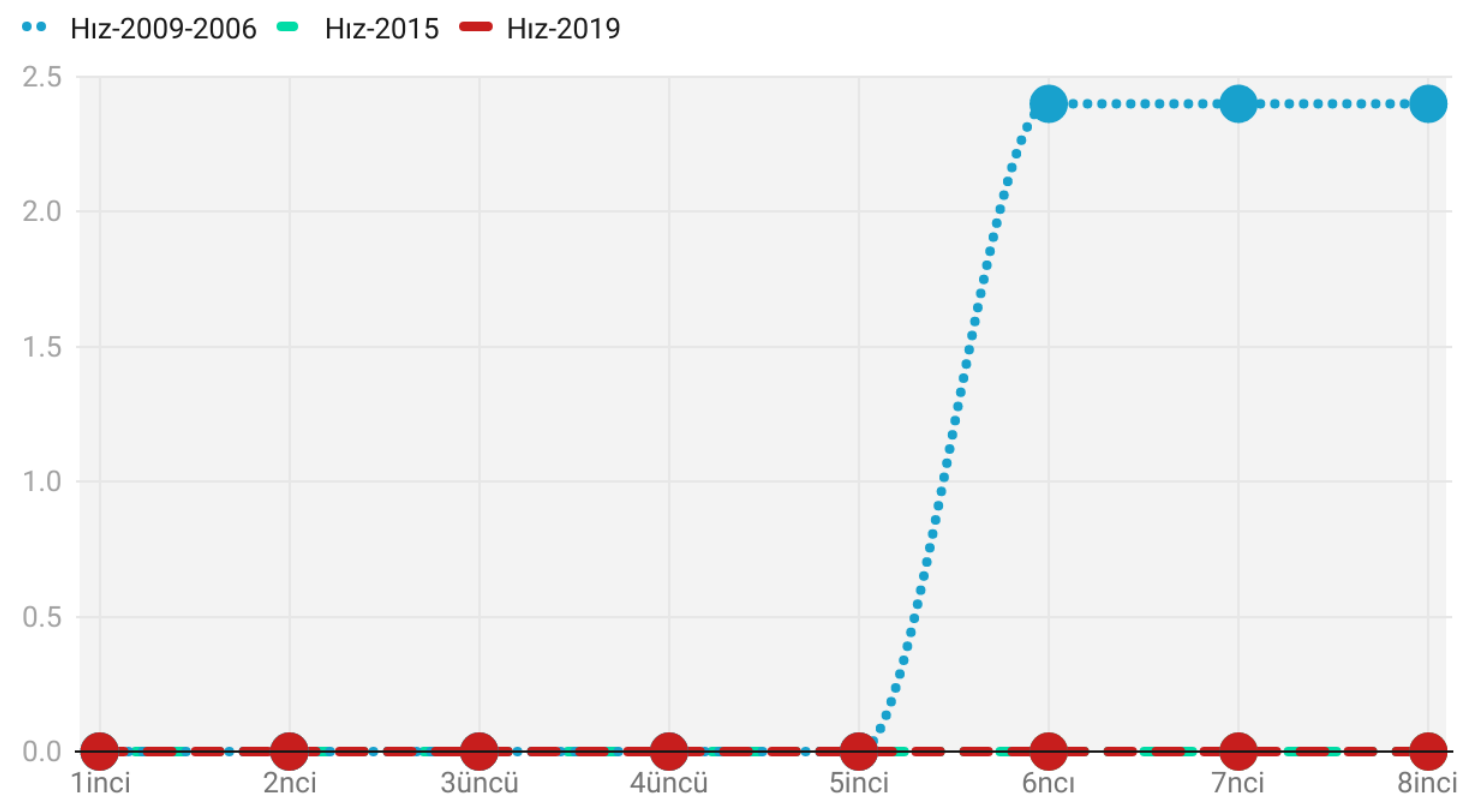

Şekil 10. 2009-2006, 2015 Ve 2019 Müfredatlarında Yazma Hızıyla İlgili Kazanımların Toplam Yazma Kazanımına Oranı

Şekil 10' da görüleceği üzere yazma hızıyla ilgili neredeyse hiçbir kazanım hiçbir müfredatta yer almamıştır. Bunun tek istisnası 2006 müfredatında yer alan "Düzgün, okunaklı ve işlek "bitişik eğik yazı"yla yazar." kazanımıdır. Bu kazanımın açıklamasında "işleklik"le ilgili olarak hızlı yazmaya 
değinilmektedir. Dolayısıyla son on beş yılda yazma hızıyla ilgili tek kazanımın olduğu, bu kazanımınsa akıcı yazmayla dolaylı olarak alakalı olduğu tespit edilmiştir.

Şekil 11'de akıcı yazmada doğrulukla ilgili kazanımların ilgili sınıf seviyelerindeki toplam yazma kazanımlarına oranları 2009-2006, 2015 ve 2019 müfredatlarına göre karşılaştırılarak verilmiştir.

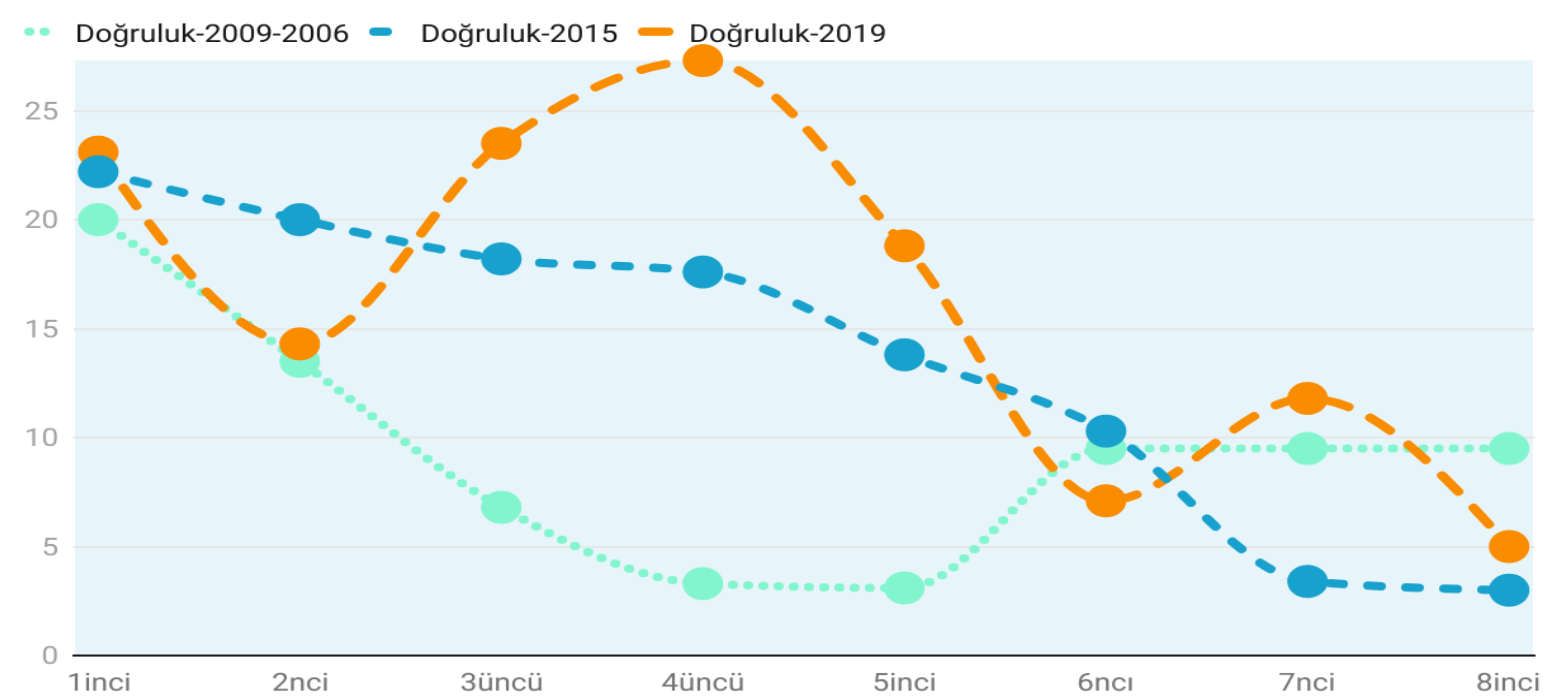

Şekil 11. 2009-2006, 2015 Ve 2019 Müfredatlarında Doğru Yazmayla İlgili Kazanımların Toplam Yazma Kazanımına Oranı

Şekil 11'de görüleceği üzere akıcı yazmada doğrulukla ilgili en düşük yüzdeler 2009 müfredatındadır. 2006 müfredatında ise diğer müfredatlardaki 6-8. sınıflara göre yer yer daha yüksek oranda doğruluk kazanımları vardır. Doğrulukla ilgili en yüksek oran 2019 programında dördüncü sınıflarda görülmektedir.

Programlar arasında 2009, 2006 ve 2015 müfredatları kendi içlerinde en tutarlı programlar olarak dikkat çekmektedir. 2009 müfredatında birinci sınıftan beşinci sınıfa kadar giderek düşen yüzdelikler görülmektedir. 2006 müfredatında 6-8. sınıfların kazanımları ortak olduğu için oranlar eşittir. 2015 müfredatında ise neredeyse düzenli bir düşüş vardır. Bu programların aksine 2019 müfredatı doğrulukla ilgili kazanımların dağıımında en düzensiz olanıdır. Mesela ikinci sınıflarda $\% 15^{\prime} l e r e$ kadar düşen oran dördüncü sınıflarda \%25'i geçip tekrar düşmüştür. Ardından yedinci sınıflarda tekrar yükselip düşmüştür.

\section{Tartışma ve Sonuç}

Çalışmanın sonuçlarına göre 2006, 2009, 2015 ve 2019 yıllarında yürürlüğe girmiş dört Türkçe öğretimi müfredatında akıcı yazmayla ilgili dolaylı bazı kazanımların olduğu fakat doğrudan ilgili bir kazanım bulunmamaktadır. Puanlayıcılar tarafından "alakalı" olarak sınıflandırılan kazanımlar aslında akıcı yazmayı hedeflemeyen ancak dolaylı olarak akıcı yazmada doğruluk boyutuna girebilecek kazanımlardır. Dolayısıyla bu müfredatlarda akıcı yazmaya yer verilmediği iddia edilebilir. Bunun tek istisnası 2006 müfredatındaki “Düzgün, okunaklı ve işlek "bitişik eğik yazı"yla yazar." kazanımındaki "işleklik" terimidir. Programda bu kazanıma yönelik yapılan açıklamada işleklikten kastedilenin hız olduğu belirtilmiştir. Akıcı yazmanın hız boyutuyla ilgili başka hiçbir kazanım veya kazanım açıklaması tespit edilememiştir.

Müfredatlarda kavram olarak "akıcı yazma"nın geçtiği hiçbir kazanım görülmemiştir. 2015 müfredatında geçen "Metin yazımında özgünlük, yalınlık, duruluk, açıklık ve akıclık özelliklerini kullanır." kazanımındaki akıcılık kavramı her iki değerlendirici tarafından bu çalışmada incelenen akıcı yazma kavramıyla alakasız olarak değerlendirilmiştir. Bunun sebebi kazanımdaki özgünlük, yalınlık, duruluk ve açıklık özelliklerinin metnin yazım süreciyle değil metnin içeriğiyle ilgili olmasıdır. Dolayısıyla bu kazanımda yer alan akıcılık özelliği metnin okunurken vereceği akıcılık hissi, yazının okuyucuyu "alıp 
sürüklemesi" manasında değerlendirilmiştir. Bu sebeple, 2006, 2009, 2015 ve 2019 Türkçe öğretimi müfredatlarında akıcı yazmanın ihmal edildiği söylenebilir.

Incelenen müfredatlarda yazma kazanımlarının sadece 2006 ve 2009 programlarında alt başıklara sahip olduğu tespit edilmiştir. Bu müfredatlarda akıcı yazmada doğruluk ve hız boyutlarıyla ilgili kazanımlar daha çok kurallarla ilgili alt başlıklarda yer bulmuştur (bkz. Tablo 1). Buradan yola çıkarak akıcı yazmayla dolaylı yoldan alakalı kabul edilen kazanımların daha çok yazma kuralı olarak görüldüğünü ifade etmek mümkündür.

2006-2009 müfredatları birlikte incelendiğinde 1-8. sınıflardaki yazma becerisi kazanımlarının toplam 273 tane olduğu, bunlardan 21'inin doğrulukla, birinin hızla ilgili olduğu görülmüştür. Genel olarak bakıldığında bu iki müfredatta akıcı yazmayla dolaylı olarak alakalı olan kazanımların oranı $\% 7,7^{\prime}$ dir. Hızla ilgili kazanımların toplam kazanıma oranı \%0,36'dır. Doğrulukla ilgili kazanımların oranı ise $\% 7,69^{\prime}$ dur.

2015 müfredatında 1-8. sınıflarda toplam 164 yazma becerisi vardır. Bunlardan hiçbiri yazma hızıyla ilgili değilken 18 tanesi $(\% 10,98)$ doğrulukla dolaylı olarak alakalıdır. 2019 müfredatında 1-8. sınıflarda toplam 133 yazma becerisi kazanımı vardır. Hızla ilgili hiçbir kazanım yokken 22 kazanım doğrulukla alakalıdır.

Akıcı yazmayla ilgili kazanımlara sınıf bazında bakıldığında en çok sayıda kazanım birinci ve ikinci sınıflarda 2009, üçüncü ve dördüncü sınıflarda 2019, beşinci sınıflarda 2015, altı, yedi ve sekizinci sınıflarda 2006 müfredatındadır (bkz. Şekil 4-5-6). Oran olarak ele alındığında birinci sınıflarda en yüksek oran 2019 'da, ikinci, üçüncü, dördüncü ve beşinci sınıflarda $2015^{\prime}$ te, altı, yedi ve sekizinci sınıflarda 2006'dadır (bkz. Şekil 7-8-9). Buradan yola çıkarak çeşitli sınıf seviyelerinde müfredatlar arasında akıcı yazmayla alakalı kazanımlarda sayı ve oran bakımından değişiklikler olduğu anlaşılmaktadır. Kimi müfredatlar sayı olarak daha fazla yer vermişken kimileri oran olarak daha fazla yer vermiştir. Ancak 6-8. sınıflarda en çok yer veren her zaman 2006 programıdır.

Akıcı yazmada hız ve doğruluk karşılaştırıldığında hızın ihmal edildiği ve gereken öneme sahip olmadığı anlaşılmaktadır. Doğruluk ise hıza göre oldukça yüksek oranlara sahiptir. Ancak doğrulukla alakalı olan kazanımlarda hedef akıcı yazma değildir. Ayrıca doğru yazmayla ilgili kazanımların sayı ve oranlarında sınıflar arasında ve müfredatlar arasında ciddi iniş çıkışlar olması da bu konuda belli bir politikanın olmadığını göstermektedir.

Yazma hızı akıcı yazmanın en önemli boyutunu oluşturmaktadır. Bunun en önemli sebebi hızlı yazabilmenin yazının içeriğinin niteliğiyle olan bağlantısıdır. Araştırmacılar yeterince hızlı yazılmadığında ve elle yazma hızının düşüncelerin hızından çok geride kaldığında yazılacakların unutulacağını, dikkatin yazının muhteviyatına odaklanması için yazma mekaniklerine ayrılmaması gerektiğini söylemektedirler (Christensen, 2009; Graham ve Weintraub, 1996; Graham vd.,1997). Öğrencilerin yazdıklarının içerik bakımından niteliklerini artırmak için yeterince hızlı yazabilmeleri gerekmektedir. Yürürlükte olan Türkçe öğretim müfredatında (MEB, 2019) metin yazmaya yönelik kazanımların nitelikli bir biçimde gerçekleştirilebilmesi öncelikle öğrencilerin akıcı yazabilmelerine bağlıdır. Öğrencilerin yavaş yazmaları yazacaklarını unutmalarına ve üst seviyeli süreçlere odaklanamamalarına sebep olacağından genelde niteliksiz metinlerin ortaya çıkacağı söylenebilir. Fakat akıcı yazmanın tek önemi nitelikli metin ortaya koymakla ilgili değildir.

Hızı (akıcı) yazabilmenin akademik başarıyla ve diğer becerilerle olan ilişkisi de dikkat çekicidir (Ahmed, 2011; Appleton, 1992; Bilge, 2019; Couvillion, 1985). Araştırmacılar akıcı yazma becerisinin sınavlarda ve dikte edici yazma vb. çalışmalarda çok mühim olduğunu ifade etmektedir (Barnett vd., 2006; Montgomery, 2006). Özellikle ilkokulun ilk basamaklarında öğrencilerin öğretmenlerinin söylediklerini yetiştirecek şekilde akıcı yazabilmeleri gerekmektedir. Sınıfın gerisinde kalan ve söyleneni kaçıran veya sınavda bildiklerini yazamadan sınavı biten öğrencilerin yazmaya karşı menfi tutum geliştirmeleri beklenir. Ortaokulda ise öğrencilerin ağır müfredat talepleriyle başa çıkabilmeleri için ödev hazırlarken, zaman sınırlı sınavlarda hızlı yazmaları gerektiğinde ve daha başka pek çok bağlamda akıcı yazmaları hayati önem taşımaktadır.

Çeşitli ülkelerin akıcı yazmayla ilgili politikaları incelendiğinde akıcı yazmaya verilen önem görülebilmektedir. Mesela İngiltere'de yürürlüğe konan bir müfredatta akıcı yazmayla ilgili kazanımlar bulunmaktadır (The National Curriculum (1989) on Handwriting and Presentation'dan aktaran; 
Montgomery, 2006). Amerikan Ulusal Yazma Komisyonu (National Comission on Writing, 2003) ise yazmanın genelde ihmal edilen bir beceri olduğunu ve akıcı yazmanın eğitimin en temel ögelerinden biri olduğunu ifade etmektedir. Araştırmacılar da yazma hızının eğitimde önemli olduğunu düşünmektedir (Montgomery, 2006; Sassoon, 2006; Ziviani ve Elkins, 1984). Amerika'da öğrencilerin akıcı yazmalarının 1984'ten itibaren takip edildiği (Ballator vd., 1999) göz önüne alındığında ülkemizin akıcı yazmaya önem verme konusunda çok geride kaldığı ortaya çıkmaktadır. Ülkemizde yapılan çalışmalarda yazmayla ilgili değişik seviyelerde zayıflıkların olduğunu gösteren pek çok bulgu olduğu bilinmektedir (Bilge, 2015; Çamurcu, 2011). Bunların en muhtemel iki sebebi ise yazmayla ilgili müfredat veya sınıftaki yazma uygulamalarıdır (Englert vd. 1988'den aktaran; Berninger ve Fuller, 1992). Bu sebeple birinci sınıftan itibaren olmak üzere hızlı ve doğru yazmaya yönelik kazanımlara yer vermenin gerektiği, akıcı yazmayla ilgili öğrencilerin düzenli takibinin mümkün mertebe yapılmasının faydalı olacağı söylenebilir. Mevcut durum göz önüne alındığında en azından son 15 yıldır öğrencilerin akıcl yazma becerisinden mahrum olarak eğitim gördükleri, kimi ülkelerde "hayati" olarak görülen bir kazanımla neredeyse hiç muhatap olmadan okul hayatlarını tamamladıkları ortaya çıkmaktadır.

Çalışmanın sonuçlarından yola çıkarak aşağıdaki önerilere yer verilmiştir:

-Millî Eğitim Bakanlığının başka ülkelerdeki akıcı yazma kazanımı ve politikalarını inceleyerek ülkemizde de gerekli düzenlemeleri yapması oldukça önemlidir.

-Öğretmenlerin öğrencilerinin akıcı yazmalarını dönem içerisinde çeşitli zamanlarda ölçerek denetlemeleri ve akıcı yazamayan öğrencilere yönelik müdahaleler geliştirmeleri ve uygulamaları tavsiye edilebilir. Yavaş yazdığı için derste not alamayan veya bildiği hâlde sadece yazma hızından ötürü sınavda düşük puan alan öğrencilerin olma ihtimali göz önünde bulundurulmalıdır.

-Araştırmacıların akıcı yazma konusuna daha fazla eğilmesi gerektiği söylenebilir. Yazma hızı ve yazmada tutukluk gibi konularda yapılan çalışmalar olsa da akıcı yazma terimi altında yapılan çalışmalar oldukça sınırlıdır.

\section{Araştırma ve Yayın Etiği}

Bu çalışmada "Yükseköğretim Kurumları Bilimsel Araştırma ve Yayın Etiği Yönergesi" kapsamında uyulması belirtilen tüm kurallara uyulmuştur. Yönergenin ikinci bölümü olan "Bilimsel Araştırma ve Yayın Etiğine Aykırı Eylemler" başlığı altında belirtilen eylemlerden hiçbiri gerçekleştirilmemiştir.

\section{Etik Kurul Izni}

Bu çalışma doküman incelemesi olduğu için etik kurul izni gerektirmemektedir.

\section{Yazarların Katkı Oranı}

Bu çalışma tek yazarlı olarak hazırlanmıştır.

\section{Çıkar Çatışması}

Bu çalışmada çıkar çatışmasına sebep olabilecek bir durum bulunmamaktadır.

\section{Destek ve Teşekkür}

Bu çalışmanın hazırlanmasındaki katkılarından dolayı Dr. Öğr. Üyesi Bahadır GÜLDEN'e çok teşekkür ederim.

\section{Kaynaklar}

Ahmed, Y. (2011). Developmental relations between reading and writing at the word, sentence and text levels: a latent change score analysis. (Yüksek lisans tezi). The Florida State University, Florida.

Akyol, H. (2015). Türkçe ilk okuma yazma öğretimi. Ankara: PegemA.

Alamargot, D., ve Fayol, M. (2009). Modelling the development of written composition. R. Beard, M. Debra, M. Nystrand, ve J. Riley (Ed.), The SAGE handbook of writing development (1st ed.) içinde. Los Angeles: SAGE. 
2006-2019 Yılları Arasında Yürürlüğe Konmuş Türkçe Öğretim Programlarının Akıcı Yazma Becerisi Bakımından Karşılaştırılması

Appleton, A. (1992). Handwriting skills of children in third through sixth-grade:relationship to academic achievement. (Doktora tezi). Fordham University, New York.

Ballator, N., Farnum, M., ve Kaplan, B. (1999). NAEP 1996 trends in writing: fluency and writing conventions. Washington, DC: U.S. Department of Education Office of Educational Research and Improvement National Center for Education Statistics.

Barnett, A., Stainthorp, R., Henderson, S., ve Scheib, B. (2006). Handwriting policy and practice in english primary schools: an exploratory study. London: Institute of Education, University of London.

Beard, R., Myhill, D., Riley, J., ve Nystrand, M. (Eds.) (2009). The SAGE handbook of writing development. Los Angeles: SAGE.

Berninger, V. W. (1999). Coordinating transcription and text generation in working memory during composing: automatic and constructive processes. Learning Disability Quarterly, 22(2), 99-112. doi:10.2307/1511269

Berninger, V. W., ve Fuller, F. (1992). Gender differences in orthographic, verbal, and compositional fluency: Implications for assessing disabilities in primary grade children. Journal of School Psychology, 30, 363-382.

Bilge, H. (2015). Ortaokul öğrencilerinin akıcı okuma becerilerinin çeşitli değişkenlere göre karşılaştırılması. (Yüksek lisans tezi). Erzincan Üniversitesi Sosyal Bilimler Enstitüsü, Erzincan.

Bilge, H. (2019). Okuma, yazma ve konuşma akıcılık ile okuduğunu anlama ve kelime hazinesi arasındaki ilişki. (Doktora tezi). Gazi Üniversitesi, Ankara.

Christensen, C. A. (2009). The critical role handwriting plays in the ability to produce high-quality written text. R. Beard, D. Myhill, J. Riley, \& M. Nystrand (Ed.), The SAGE handbook of writing development (pp. 284-299) içinde. London: SAGE.

Couvillion, P. M. (1985). The use of handwriting and copying rate for predicting academic achievement, academic performance and assignment completion. (Doktora tezi). The Florida State University, Florida.

Çamurcu, D. (2011). Yüksek öğrenimine yeni başlayan Türkçe eğitimi bölümü öğrencilerinin yazma becerilerinin incelenmesi. Selçuk Üniversitesi Türkiyat Araştırmaları Dergisi, 29, 503-518.

Dockrell, J. (2009). Causes of delays and difficulties in the production of written text. R. Beard, D. Myhill, J. Riley, ve M. Nystrand (Ed.), The SAGE handbook of writing development (pp. 489-505) içinde. Los Angeles: SAGE.

Eldeleklioğlu Onuk, D., ve Avcı, B. (2021). Okuma becerileri dersi öğretim programının incelenmesi. Ana Dili Eğitimi Dergisi, 9(2), 343-359.

Galbraith, D. (2009). Writing about what we know: genereting ideas in writing. R. Beard, D. Myhill, J. Riley ve M. Nystrand (Ed.), The SAGE handbook of writing development (pp. 48-64) içinde. London: SAGE.

Graham, S., Berninger, V. W., Abbott, R. D., Abbott, S. P., ve Whitaker, D. (1997). Role of mechanics in composing of elementary school students: a new methodological approach. Journal of Educational Psychology, 89(1), 170-182.

Graham, S., ve Weintraub, N. (1996). A review of handwriting research: progress and prospects from 1980 to 1994. Educational Psychology Review, 8(1), 7-87.

Hayes, J. R. (2009). From idea to text. R. Beard, D. Myhill, M. Nystrand, ve J. Riley (Ed.), The SAGE handbook of writing development (pp. 65-79) içinde. London: SAGE.

Hestad, L. C. (2014). The impact of vocabulary instruction on writing fluency. (Doctoral Thesis). Walden University, Minnesota.

Hudson, R. F. (2002). Compositional fluency and spelling accuracy of second-grade students under six priming conditions. (Doktora tezi). University of Florida, Florida.

Kaptan, A. (2015). ilköğretim beşinci sınıf öğrencilerinin ikna edici yazma beceri düzeylerinin belirlenmesi. (Yüksek lisans tezi). Eskişehir Osmangazi Üniversitesi Eğitim Bilimleri Enstitüsü, Eskişehir.

Kaynaş, E. (2014). Beşinci sınıf öğrencilerinin öyküleyici metin yazma becerilerinin değerlendirilmesi. (Yüksek lisans tezi). Eskişehir Osmangazi Üniversitesi Eğitim Bilimleri Enstitüsü, Eskişehir. 
Lannin, A. A. (2007). Freewriting for fluency and flow in eighth and ninth grade reading classes. (Doktora tezi). University of Missouri, Columbia.

MEB. (2006). Ilköğretim Türkçe dersi öğretim programı ve kılavuzu (6,7,8. sınıflar). Ankara: MEB Yayınları

MEB. (2009). Illköğretim Türkçe dersi öğretim programı ve kılavuzu (1-5. sınıflar). Ankara: MEB Yayınları

MEB. (2015). Türkçe dersi (1-8. sınıflar) öğretim programı. Ankara: T.C. Millî Eğitim Bakanlığı Talim ve Terbiye Kurulu Başkanlığı.

MEB. (2019). Türkçe dersi öğretim programı (ilkokul ve ortaokul 1, 2, 3, 4, 5, 6, 7, 8. sınıflar). Ankara: T.C. Millî Eğitim Bakanlığı.

Miles, M., Huberman, M., ve Saldana, J. (2014). Qualitative data analysis: a methods sourcebook (3th ed.): Thousand Oaks: SAGE Publications.

Montgomery, D. (2005). Cohort analysis of writing in Year 7 following 2, 4 and 7 years of the National Literacy Strategy. British Educational Research Association Annual Conference'ta sunulan bildiri, London.

Montgomery, D. (2006). Spelling, handwriting and dyslexia: overcoming barriers to learning. London: Routledge.

National Comission on Writing. (2003). Report of the neglected " $R$ " the need for a writing revoluation in America's schools and colleges. New York: College Entrance Examination Board.

Patton, M. Q. (2002). Qualitative research \& evaluation methods. London: SAGE Publications.

Sassoon, R. (2005). Handwriting: the way to teach it. London: Paul Chapman Publishing.

Sassoon, R. (2006). Handwriting problems in the secondary school. London: Paul Chapman Publishing.

Sawyer, C., Francis, M., ve Knight, E. (1992). Handwriting speed, specific learning difficulties and the GCSE. Educational Psychology in Practice, 8(2), 77-81.

Silverman, D. (2018). Doing qualitative research (5th ed.). London: SAGE Publications.

Stanovich, K. E. (2009). Matthew effects in reading: Some consequences of individual differences in the acquisition of literacy. Reading Research Quarterly, 189(1-2), 23-55.

Wolfe-Quintero, K., Inagaki, S., ve Kim, H.-Y. (1998). Second language development in writing: measures of fluency, accuracy \& complexity. Honolulu, Hawaii: University of Hawaii at Manoa.

Yıldırım, A., ve Şimşek, H. (2004). Sosyal bilimlerde nitel araştırma yöntemleri. Ankara: Seçkin.

YÖKTEZ. (2021). Lisansüstü tez veri tabanı. Erişim adresi: https://tez.yok.gov.tr/UlusalTezMerkezi/

Ziviani, J., ve Elkins, J. (1984). An evaluation of handwriting performance. Educational Review, 36(3), 249-261.

\section{Introduction}

\section{Extended Abstract}

Very complex mental processes occur during the creation of a written text. The existence of production, transmission and review processes in cognitive process models were proposed to explain how writing occurs and are commonly accepted by researchers (Alamargot \& Fayol, 2009; Beard, Myhill, Riley, \& Nystrand, 2009). Failure in any of these processes can affect the whole process.

Writing fluency is defined in different ways, such as writing quickly, effortlessly, accurately and ensuring the consistency of ideas in the written text (Hudson, 2002; Lannin, 2007; Wolfe-Quintero, Inagaki, \& Kim, 1998). Although it is possible to include different dimensions among the definitions of writing fluency, measurements are generally made in terms of speed and time. In many studies, speed is taken as a measure of fluency, and the number of elements such as letters, words, clauses, and sentences per unit is measured (Berninger \& Fuller, 1992; Bilge, 2019; Hestad, 2014; Hudson, 2002; Lannin, 2007).

In this study, the aim was to examine the place of writing fluency in the 2006, 2009, 2015 and 2019 Turkish teaching curricula. Thus, it will be possible to determine how many gains have been achieved about writing fluency in the last fifteen years and whether there is consistency between the curricula. 


\section{Method}

In this study, the place of writing fluency in Turkish teaching curricula, which were implemented in the last fifteen years, was examined. The data collection method in the research conducted with a qualitative design is document analysis. Document analysis can be used alone or in addition to other qualitative methods and is a method for examining a wide variety of documents such as photos, books, audio recordings, etc. (Yıldırım \& Şimşek, 2004).

In this study, the curricula confirmed by the Ministry of National Education (MoNE) were used as data resources. In this context, four Turkish language arts teaching curricula (MoNE, 2006, 2009; 2015, 2019) constitute the basic data resources for the research. The 2017 and 2018 syllabuses were excluded as they are almost the same as the 2019 syllabus.

In this study, in which document analysis was conducted, descriptive analysis was used to analyze the data. Descriptive analysis is a type of analysis that can be used in qualitative research which evaluates according to pre-decided classes and aims to present descriptive data to readers (Yıldırım \& Şimşek, 2004).

Before analyzing the data, definitions of writing fluency in the literature were reviewed. Since there are many different definitions and measurements, this study was based on writing fluency measurements in Bilge's (2019) research. Accordingly, learning outcomes in writing fluency (speed and correct spellings of words only) were examined. Expression disorders were not evaluated in the dimension of "accuracy".

With the data obtained, the total numbers and percentages of the learning outcomes related or not related to writing fluency were calculated. Analyses are presented as frequency and percentage. In order to facilitate the understanding of the data, the 2009 and 2006 curricula are presented together.

All writing outcomes in the four curricula examined in the study were labelled on the form by the researcher. Then, the same form was completed by an academic with a PhD degree in Turkish education. Then, the two evaluators met and evaluated the outcomes involving differences of opinion. After the discussions, some of the outcomes were compatible, while the inconsistency between the evaluators continued for others.

The compatibility obtained after the first and second evaluations of the evaluators were analyzed with the formula of Miles and Huberman (cited from 1994; Eldeleklioğlu Onuk \& Avcl, 2021). Compatibility for all evaluations was $86 \%$ and above.

\section{Result and Discussion}

According to the results of the study, outcomes "related to" and "not related to" writing fluency were determined in four curricula that were implemented in the last fifteen years. The outcomes classified as "related" by the evaluators did not actually target writing fluency, but indirectly affect the dimension of accuracy in writing fluency. Therefore, it can be claimed that writing fluency was not included in these curricula. The only exception to this is the "productive" term in the "writes in neat, legible and productive "cursive handwriting" learning outcome in the 2006 curriculum. In the statement made about this outcome in the curriculum, speed is stated to be represented by the term 'productive'. No other outcome or explanation of outcomes could be detected regarding the speed dimension of writing fluency. There were inconsistencies between the curricula and grade levels in terms of fluent writing. As a result, it is possible to say that writing fluency has been neglected in Turkish teaching programs that were implemented since 2006. 